\title{
Trends in co-prescribing of angiotensin converting enzyme inhibitors and angiotensin receptor blockers in Ireland
}

Correspondence

Dr Wan A. H. Wan Md Adnan, Senior Lecturer, Nephrology Unit, Department of Medicine, Faculty of Medicine, University Malaya, Kuala Lumpur, Malaysia.

Tel.: +60(13)3361306

Fax:+603-79494613

E-mail:wahafiz@um.edu.my

\section{Keywords}

ACE inhibitor, angiotensin receptor blocker, co-prescribing, prescribing patterns

Received

9 April 2010

Accepted

17 October 2010

\section{Wan A. H. Wan Md Adnan,, ${ }^{1,4}$ Nur L. Zaharan,, ${ }^{2,3}$ Kathleen Bennett ${ }^{2} \&$ Catherine A. Wall ${ }^{1}$ \\ 'Department of Renal Medicine, Adelaide \& Meath Hospital Incorporating National Children Hospital (AMNCH), Dublin 24, ${ }^{2}$ Department of Pharmacology \& Therapeutics, Trinity Centre of Health Sciences, St James's Hospital, Dublin 8, Ireland, ${ }^{3}$ Department of Pharmacology, University Malaya, and ${ }^{4}$ Nephrology Unit, Department of Medicine, Faculty of Medicine, University Malaya, Kuala Lumpur, Malaysia}

\section{WHAT IS ALREADY KNOWN ABOUT} THIS SUBJECT

- Renin-angiotensin-aldosterone system inhibition confers cardio-renal protection and may be achieved by monotherapy with an angiotensin enzyme converting inhibitor (ACEI) or an angiotensin-II receptor blocker (ARB).

- Dual ACEI and ARB therapy has been examined in major clinical trials with conflicting results.

- The prescribing pattern of dual therapy in general primary care population is not known.

\section{WHAT THIS STUDY ADDS}

\section{- An increase in the co-prescribing of ACEls} and ARBs was observed in the Irish primary care population.

- Co-prescribing of ACEls and ARBs in the primary care population did not appear to be influenced by results from major clinical trials.

- ACEls and ARBs were more likely to be co-prescribed in special cohorts of the population with diabetes, hypertension and heart failure.

\section{AIMS}

(i) To examine the trends in co-prescribing of angiotensin converting enzyme inhibitor (ACEI) and angiotensin-II receptor blocker (ARB) therapy and (ii) to examine the influence of major clinical trials (CALM, COOPERATE, VALIANT and ONTARGET) on co-prescribing.

\section{METHODS}

The Irish HSE-Primary Care Reimbursement Services database was used to identify patients $\geq 16$ years old co-prescribed ACEls and ARBs between January 2000 and April 2009 ( $n=266554$ prescriptions). The rate of prescribing per 1000 general medical services (GMS) scheme population was calculated for each month. Patients with diabetes, hypertension, heart failure and ischaemic heart disease were also identified by prescribing of certain medications. A linear trend test was used to examine prescribing trends. Logistic regression was used to examine prescribing according to patient characteristics. The effects of the major trials on prescribing were examined using segmented regression analysis for 12 months pre- and post-trials.

\section{RESULTS}

There was a significant linear trend in overall ACEI and ARB co-prescribing over the study period $(P<0.001)$. Rate of co-prescribing in January 2000 and April 2009 was 0.16 and 5.72, per 1000 eligible population, respectively. Those 45-64 years old $(\mathrm{OR}=2.88,95 \%$ confidence interval $(\mathrm{Cl}) 2.71,3.06)$ and $\geq 65$ years $(\mathrm{OR}=2.52,95 \% \mathrm{Cl} 2.36,2.68)$ were more likely to receive dual therapy compared with those $<45$ years old. Those with hypertension $(\mathrm{OR}=8.85,95 \% \mathrm{Cl} 8.45,9.27)$ diabetes $(\mathrm{OR}=4.10,95 \% \mathrm{Cl} 3.97,4.23)$ and heart failure $(\mathrm{OR}=1.78,95 \% \mathrm{Cl} 1.72$, 1.84) were more likely to receive dual therapy compared with the general population. Significant increases in prescribing were observed only after the CALM $(P=0.03)$ and VALIANT $(P=0.007)$ trials.

\section{CONCLUSION}

Increased co-prescribing of ACEls and ARBs was observed in Ireland during 2000-09. Prescribing patterns did not appear to be affected by results from major trials. 


\section{Introduction}

The renin-angiotensin-aldosterone system (RAAS) plays an important role in hypertension, cardiovascular and renal disease. Inhibition of RAAS confers some protection from cardio-renal clinical endpoints and may be achieved by the use of angiotensin converting enzyme inhibitors (ACEls), angiotensin-II receptor blockers (ARBs) and recently, direct renin inhibitor therapies. Monotherapy with ACEls, ARBs or direct renin inhibitors has been shown to have clinical benefits beyond its blood pressure lowering effects $[1,2]$. Thus, combination therapy of ACEls and ARBs was thought to be advantageous compared with monotherapy and may be prescribed for patients with heart failure $[3,4]$, hypertension [4-6] and proteinuria $[5,7,8]$.

Randomized clinical trials on the use of combination therapy present conflicting results. The Candesartan and Lisinopril Microalbuminuria (CALM) trial showed greater reduction in blood pressure and microalbuminuria with the combination of ACEls and ARBs compared with monotherapy of either agent in patients with hypertension, microalbuminuria and diabetes [5]. Another favourable outcome was observed in The Combination Treatment of Angiotensin-II receptor Blocker and Angiotensin Converting Enzyme Inhibitor in Non-diabetic Renal Disease (COOPERATE) trial which showed slower progression of nondiabetic renal disease with a combination of ACEl and ARB therapy compared with monotherapy [7]. However the most recent combination therapy trial, The Ongoing Telmisartan Alone and in Combination with Ramipril Global Endpoint Trial (ONTARGET) which recruited patients with high risk vascular events showed no significant benefit of combination therapy. Furthermore, increased adverse events such as hypotensive episodes, syncope and renal dysfunction were observed [6]. ONTARGET was preceded by another trial, Valsartan in Acute Myocardial Infarction Trial (VALIANT), which demonstrated an increase in adverse events for patients prescribed combination therapy and no improvement in the survival rates for post myocardial infarction patients with heart failure [9].

Since the publication of the ONTARGET trial, physicians have differed in the interpretation of the benefits of combination therapy. In 2009, the Canadian Hypertension Society recommended that a combination of an ACEl and ARB be avoided in hypertensive patients without heart failure or proteinuria [10]. Messerli in his review strongly discouraged the use of dual ACEI and ARB therapy [11]. Others have taken a more cautious approach and have advised close monitoring for potential adverse effects [12].

Our study was undertaken to examine the trends in the co-prescribing of ACEls and ARBs in Ireland from January 2000 to April 2009 across age and gender and in specific cohorts of patients with diabetes, hypertension, heart failure and ischaemic heart disease (IHD). In addition, the influence of the four major clinical trials on the co-prescribing of ACEls and ARBs was also examined.

\section{Methods}

Data source

This study was performed using the Irish Health Service Executive - Primary Care Reimbursement Services (HSEPCRS) national primary care prescribing database. The HSEPCRS provides free health services under the general medical services (GMS) scheme including the provision of prescription medications. The eligibility for the GMS scheme is means tested for those less than 70 years of age and free for all 70 years and over (from July 2001 to December 2008). The scheme is therefore over represented by females, socio-economically deprived and elderly people. The scheme covered approximately $33 \%$ of the total population in Ireland, or 1.2 million individuals in 2007 [13].

The HSE-PCRS database records all prescriptions dispensed by pharmacists throughout Ireland for claims purposes from the GMS scheme. Full details on medications dispensed were recorded in the database using the WHO Anatomical Therapeutic Chemical (ATC) classification system. Basic demographic information such as age, gender, regions and general practitioners are available in the database. However, clinical diagnosis is not recorded in the database. The prescription database has been used widely for research purposes in Ireland.

\section{Patient population}

The Irish HSE-PCRS database was used to identify patients 16 years old and over prescribed any medications between 1 January 2000 and 30 April 2009 ( $n=2192$ 227). From the study population, patients co-prescribed ACEls (ATC = C09A, C09B) and ARBs (ATC = C09C, C09D) in the same prescription claim form were identified $(n=18337$, 266554 prescriptions). In addition, the presence of hypertension, diabetes, heart failure and IHD were identified using prescriptions as surrogate markers for the diseases. Patients with three or more prescriptions of (i) major classes of anti-hypertensive agents besides ACEls and ARBs: $\beta$-adrenoceptor blockers (ATC $=\mathrm{C07}$ ), diuretics (ATC $=$ C03A, C03B), or calcium channel blockers (ATC $=$ C08) as markers of hypertension ( $n=467582$ ), (ii) insulin (ATC = A10A) or oral hypoglycaemic agents (ATC $=$ A10B) as markers for diabetes mellitus ( $n=101263$ ), (iii) high ceiling loop diuretics (ATC $=\mathrm{CO3C}$ ) as markers of heart failure $(n=$ 207658 ) and (iv) nitrate (ATC $=$ C01DA) or nicorandil (ATC $=$ C01DX16) with aspirin (ATC $=$ B01AC06, N02BA01) as markers of IHD ( $n=84364)$ were identified to examine the trends in co-prescribing of ACEls and ARBs in these cohorts.

\section{Statistical analysis}

The rate of co-prescribing of ACEls and ARBs per 1000 GMS eligible population was calculated for each month from January 2000 to April 2009 (112 months) and according to gender and age groups (defined as 16-44, 45-64 and $\geq 65$ 
years old). The co-prescribing rates in cohorts with hypertension, diabetes, heart failure and IHD were also calculated. A test for linear trend using regression analysis was used to examine the trends in co-prescribing of ACEls and ARBs over the study period. Logistic regression was used to calculate the odds ratio (OR) and $95 \%$ confidence intervals (Cl) of ACEI and ARB co-prescribing in females compared with males and in age groups 45-64 years and 65 years and above compared with those below 45 years old. The OR with $95 \% \mathrm{Cls}$ adjusted for age and gender in those with diabetes, heart failure, hypertension or IHD were calculated compared with the general GMS population without these conditions.

The effects of the four major clinical trials on the co-prescription of ACEls and ARBs was examined using segmented regression analysis [14]. The 12-month period before and after the respective clinical trials was used for this purpose; January 2000 to December 2001 for the CALM trial [5], January 2002 to December 2003 for the COOPERATE trial [7], December 2002 to November 2004 for the VALIANT trial [9] and May 2007 to April 2009 for the ONTARGET trial [6].

Analysis was performed using SAS version 9.1 (SAS institute Inc., Cary, USA). Significance at $P<0.05$ is assumed.

\section{Results}

Eighteen thousand three hundred and thirty-seven patients (52\% males, $58 \% \geq 65$ years old) co-prescribed ACEl and ARB therapy in the same prescription claim forms were identified from 1 January 2000 to 30 April 2009. This accounted for $0.3 \%$ of the total GMS population over 9 years. Of those co-prescribed ACEls and ARBs, $84 \%$ were also prescribed other major classes of anti-hypertensive agents. In addition, 35\% were prescribed medications for diabetes, $41 \%$ received medication for heart failure and $17 \%$ received medication for IHD.

Overall, there was a significant increase in the rate of ACEI and ARB co-prescribing over the 112-month period. The rate of prescribing was 0.16 per 1000 GMS eligible population in January 2000 and increased to 5.10 per 1000 GMS eligible population in April $2009(P<0.0001)$ as presented in Figure $1 \mathrm{~A}$. The highest prescribing rate of 5.98 per 1000 GMS eligible population was observed in December 2008. This increasing trend in co-prescribing of ACEls and ARBs was observed in both males (0.41 in January 2000, 5.90 in April 2009) and females (0.17 in January 2000, 4.49 in April 2009) (Figure 1B). The increasing co-prescribing trend was also observed in the three different age groups $(P<0.0001)$ with the highest rate of co-prescribing observed in those aged over 65 years old and over (Figure 1C).

The rate of co-prescribing also significantly increased over the study period in the cohorts of patients with hypertension, diabetes, heart failure and IHD $(P<0.0001)$ as pre- sented in Figure 2. The highest increase in rate of prescribing was observed in patients with diabetes ( 0.97 in January 2000, 25.72 in April 2009), followed by patients with hypertension (0.59 in January 2000, 12.72 in April 2009), heart failure (0.77 in January 2009, 12.07 in April 2009) and IHD (0.35 in January 2000, 10.43 in April 2009).

Females were significantly less likely to be prescribed dual therapy compared with males in the general GMS population as presented in Table 1. Those aged over 45 years old were significantly more likely to be prescribed dual therapy compared with those aged less than 45 years old. Patients prescribed other major anti-hypertensive agents were nearly nine times more likely and those prescribed diabetes therapies were four times more likely be to be co-prescribed ACEI and ARB therapy compared with those without the diseases in the general GMS population. There was no significant increase in prescribing of combination therapy in patients with IHD after adjustment for age and gender.

Overall, there were significant increases in co-prescribing after the CALM $(P=0.001)$ and VALIANT ( $P=$ $0.01)$ trials, but no significant changes in co-prescribing patterns were observed after the COOPERATE $(P=0.09)$ and ONTARGET $(P=0.2)$ trials as shown in Table 2. However a decreasing trend was observed after the ONTARGET trial. In sub-group analyses, significant increases in co-prescribing were observed in both males and females, those with hypertension, diabetes, heart failure and IHD and in age groups $16-45$ years and $\geq 65$ years after the CALM trial. Although no significant change was observed in the overall co-prescribing trend after the COOPERATE trial, further analyses showed significant increases in co-prescribing for males $(P=0.04)$, IHD $(P=0.004)$ and a marginal but statistically significant increase in those with heart failure $(P=0.046)$. Co-prescribing after the VALIANT trial was significantly increased in both males $(P=0.02)$ and females $(P=0.02)$, those aged $\geq 65$ years $(P=0.01)$ and those with hypertension $(P=0.03)$ and diabetes $(P=0.01)$. Co-prescribing for patients with IHD showed a nonsignificant negative trend. Following publication of the ONTARGET trial, there were decreases in co-prescribing of ACEls and ARBs across all groups, although this only reached statistical significance in those aged 16-44 years $(P=0.04)$ and patients with IHD $(P=0.007)$.

\section{Discussion}

There was an increasing trend in the co-prescribing of ACEls and ARBs in Ireland over the study period. Increased prescribing trends were observed in males and females, in all age groups and in those with hypertension, diabetes and heart failure. Prescribing trends reflect the previously held view that co-prescribing of ACEls and ARBs is beneficial from the cardio-renal perspective. These trends are also consistent with another study that showed an increase in 

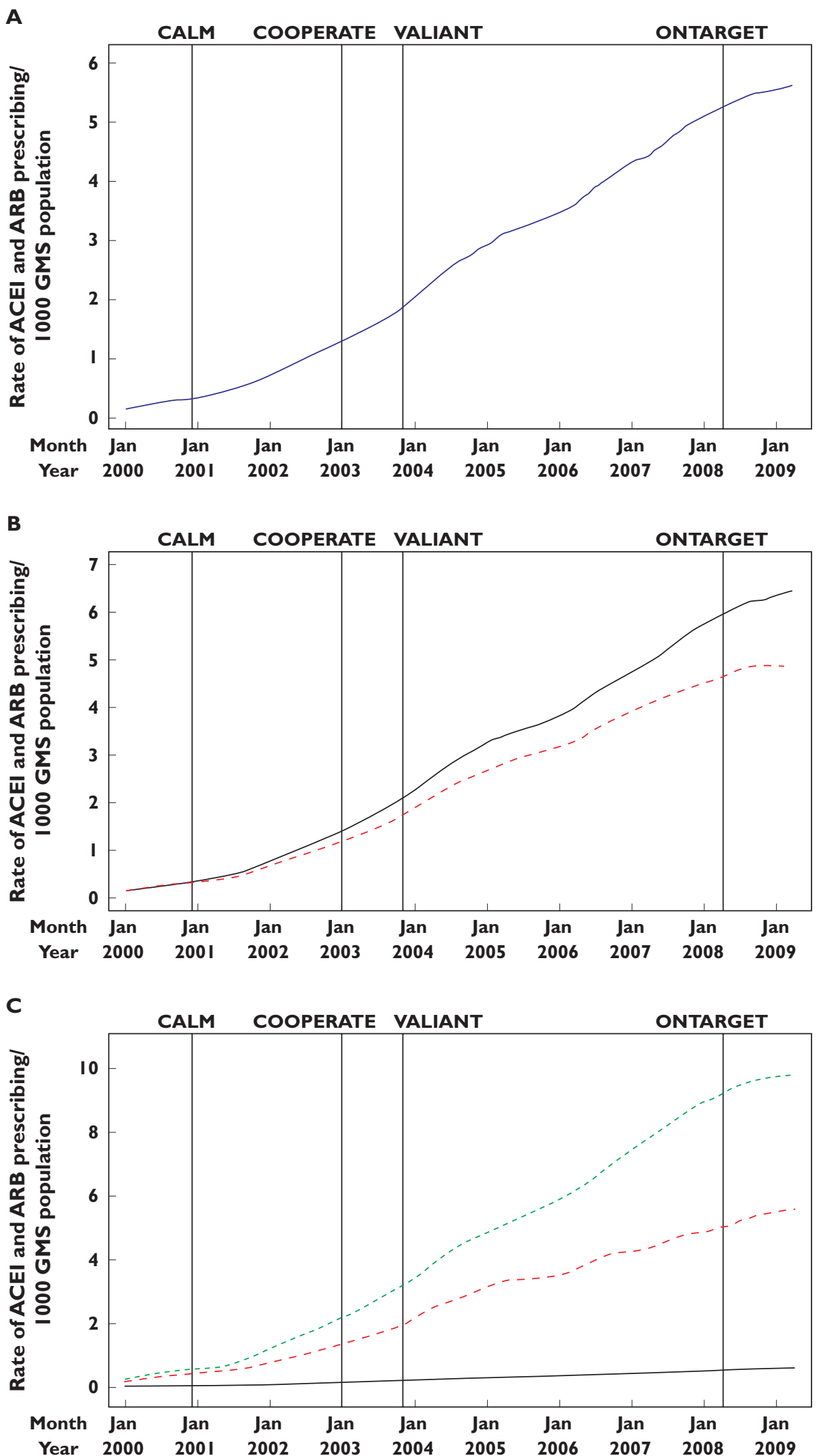

Figure 1

Rate of co-prescribing of ACEls and ARBs per 1000 GMS population (A) from January 2000 to April 2009, (B) according to gender from January 2000 to April 2009 and (C) according to different age groups from January 2000 to April 2009, with intersections representing four major trials. (B) Rate/1000 Males GMS (-); Rate/1000 Females GMS (- -); Rate/1000 aged 16-44 years GMS (-); (C) Rate/1000 aged 45-64 years GMS (- -); Rate/1000 aged >65 years GMS (- - ) 


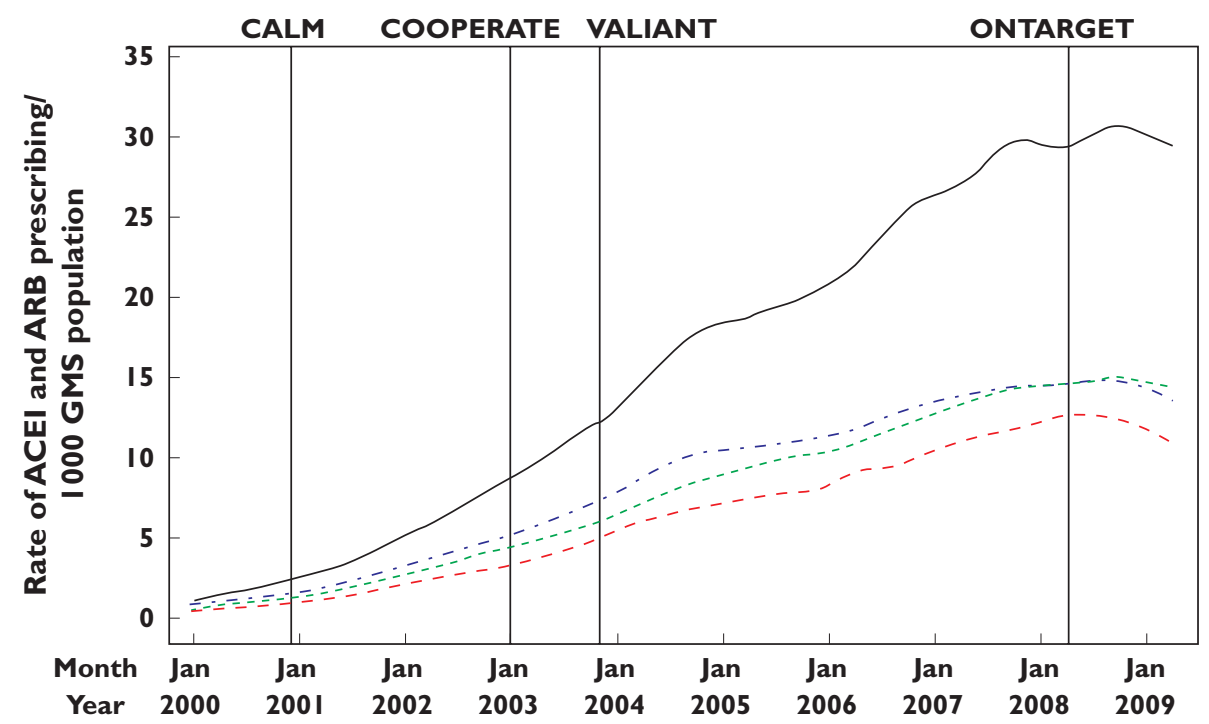

\section{Figure 2}

Rate of co-prescribing of ACEls and ARBs per 1000 GMS population according to the presence of specific diseases from January 2000 to April 2009 , with intersections representing four major trials. Rate/1000 diabetes (-); Rate/1000 IHD (- -); Rate/1000 HTN (- - ); Rate/1000 CHF (- -)

\section{Table 1}

Adjusted OR (and 95\% Cls) of co-prescribed ACEls and ARBs according to patient characteristics in the Irish GMS population ( $n=2192227)$

\begin{tabular}{|c|c|c|c|c|c|c|}
\hline Characteristics & $\begin{array}{l}\text { Unadjusted } \\
\text { OR }\end{array}$ & $95 \% \mathrm{Cl}$ & $\boldsymbol{P}$ & $\begin{array}{l}\text { Adjusted* } \\
\text { OR }\end{array}$ & $95 \% \mathrm{Cl}$ & $\boldsymbol{P}$ \\
\hline Femalest ( $n=1239$ 566) & 0.84 & $0.81,0.85$ & *** & 0.96 & $0.93,0.99$ & 0.007 \\
\hline Age $>65$ years $¥(n=553250)$ & 15.13 & $14.34,15.97$ & *** & 2.52 & $2.36,2.68$ & $* \star *$ \\
\hline Hypertension§ ( $n=467$ 482) & 20.33 & $19.54,21.16$ & *** & 8.85 & $8.45,9.27$ & $* \star *$ \\
\hline Diabetes§ $(n=101263)$ & 11.63 & $11.28,12.08$ & *** & 4.1 & $3.97,4.23$ & $* * *$ \\
\hline
\end{tabular}

*Adjusted for gender, age groups and presence of specific disease (using prescription medications as marker). tReference category males. \#Reference category age 16-44 years. §Reference category general GMS population without the disease. ${ }^{* * * P}<0.0001$. NS, not significant.

the prescribing of ACEl in Ireland from year 2000 to year 2005 [15]. Other studies in Irish diabetic and IHD patients showed a trend towards increasing use of ACEls over the past years as preventative cardiovascular therapy $[16,17]$. The increase in co-prescribing may be explained by increases in the prevalence of diseases such as hypertension [18] and diabetes [19] as well as the cumulative effects of early favourable trials of ACEls and ARBs. The number of adults with hypertension in Ireland is expected to increase from 852000 in 2007 (25.1\%) to 1192000 (28.3\%) in 2020 which represents a $40 \%$ increase. In addition, adults with diabetes are expected to increase by more than $60 \%$ by 2020 [20]. Even so, there was no specific guideline recommending the use of combination therapy in any clinical conditions during the early study period.

The co-prescribing of ACEls and ARBs is higher in males compared with females. This may be due to the fetotoxic effects of ACEls and ARBs suggesting that these agents may generally be avoided in women of reproductive age $[21,22]$. Higher rates of co-prescribing in older age groups may reflect increased co-morbidities with advancing age. Both agents have been demonstrated to be safe and efficacious in treating hypertension in the elderly although guidelines recommend the use of calcium channel blockers and diuretics as first line agents in the elderly [23]. The co-prescribing of ACEls and ARBs is significantly higher in those with hypertension, diabetes and heart failure but not in those with IHD compared with the general population. ACEls or ARBs have been used extensively as monotherapy in accordance with guidelines in those with hypertension [24], diabetes with microalbuminuria [25], heart failure [26] and post myocardial infarction [27] for cardio-renal protection which might explain the higher co-prescribing rates in these cohorts of patients. The use of both ACEls and ARBs 


\section{Table 2}

The influence of major clinical trials on co-prescribing of ACEls and ARBs shown as change in the rate of prescribing (value of change in slope) 12 months post-trial compared with 12 months pre-trial

\begin{tabular}{|c|c|c|c|c|c|c|c|c|}
\hline Trials & $\begin{array}{l}\text { CALM } \\
\text { (December 2000) } \\
\text { Change in slope* }\end{array}$ & $\boldsymbol{P}$ & $\begin{array}{l}\text { COOPERATE } \\
\text { (January 2003) } \\
\text { Change in slope* }\end{array}$ & $P$ & $\begin{array}{l}\text { VALIANT } \\
\text { (November 2003) } \\
\text { Change in slope* }\end{array}$ & $P$ & $\begin{array}{l}\text { ONTARGET } \\
\text { (April 2008) } \\
\text { Change in slope* }\end{array}$ & $P$ \\
\hline Male & 3.86 & 0.001 & 2.18 & 0.04 & 2.42 & 0.02 & -1.44 & NS \\
\hline Female & 2.80 & 0.01 & 1.21 & NS & 2.5 & 0.02 & -0.95 & NS \\
\hline Aged $16-44$ years & 2.88 & 0.009 & -1.64 & NS & 1.65 & NS & -2.07 & 0.04 \\
\hline Aged $45-65$ years & 1.14 & NS & 1.71 & NS & 1.16 & NS & -1.10 & NS \\
\hline Diabetes & 3.10 & 0.005 & 1.41 & NS & 2.70 & 0.01 & -0.27 & NS \\
\hline Heart failure & 3.94 & 0.001 & 2.12 & 0.046 & 0.70 & NS & -1.58 & NS \\
\hline IHD & 2.62 & 0.01 & 3.25 & 0.004 & -1.44 & NS & -3.03 & 0.007 \\
\hline
\end{tabular}

*Positive value for change in slope indicates increase in prescribing after compared with before trial, and negative slope a decrease in prescribing after compared with before. NS, not significant.

in patients with IHD or, more specifically, myocardial infarction was investigated in the VALIANT trial and the result was not favourable for this group of patients [9].

The CALM and COOPERATE trials demonstrated favourable outcomes for combination therapy of ACEls and ARBs, while the VALIANT and ONTARGET trials showed inferior outcomes compared with monotherapy. Except for the CALM trial, the other major clinical trials appear to have had little impact on the co-prescribing patterns of ACEls and ARBs. In Ireland, most major clinical trials did not demonstrate any influence on prescribing of antihypertensives with the exception of the ALLHAT trial [15]. Prescribing patterns and clinical implementation usually lag behind the publication of clinical studies and guidelines [28, 29]. Therefore, the 12-month study period may not have been long enough to reflect the true prescribing pattern. However, extending the study period beyond 12 months would make the interpretation of data more difficult because of the overlap between the studies involved. In the past, media reports have had a strong influence on prescribing patterns in Ireland. The decline in prescribing of co-trimoxazole preceded the change in its license indication by the Irish Medicine board [30]. Pharmaceutical marketing also influences the medications prescribed in primary care [31]. In Ireland, lipid lowering medication showed the widest increase in prescription between 1997 to 2003 compared with its European counterparts [32]. Atorvastatin was the most commonly prescribed statin in Ireland in 2007 despite its high cost, with other lower costing generic statins such as pravastatin or simvastatin less frequently prescribed [33], suggesting the potential major influence from pharmaceutical industries on medication prescribing in Ireland.

Interestingly, following the ONTARGET trial, a downward trend in co-prescribing of ACEls and ARBs was identified, although this did not reach statistical significance.
The influence of the ONTARGET study published in April 2008 on prescribing might have been underestimated as the ONTARGET investigators only highlighted worse renal outcomes with combination therapy in August 2008 [34]. Therefore, the result of the latest combination therapy trial, combination angiotensin receptor blocker and angiotensin-converting enzyme inhibitor for treatment of diabetic nephropathy (VA NEPHRON-D), may help to further clarify the issue [35].

\section{Strengths and limitations}

To our knowledge, this is the first study to examine the impact of four major trials, CALM, COOPERATE, VALIANT and ONTARGET, on patterns of co-prescribing of ACEls and ARBs in specific populations. The national prescribing databases used in this study are large and include patients selected from all regions in Ireland. The use of retrospective data enabled a longitudinal history of prescribed medications over a 9-year period to be examined at an individual level. The inclusion of only those who received ACEls and ARBs on the same prescription claim form reduced the risk of patients being prescribed both therapies unintentionally or those switching from one therapy to another.

Cohorts of patients with diabetes, heart failure, hypertension and IHD were identified using surrogate prescribing markers. This method has been used in several other studies [36-38]. However, the lack of definitive diagnosis was the main concern. The use of furosemide as a marker of heart failure will possibly overestimate the true prevalence of the disease and may overlap with the diagnosis of liver and kidney disease, in the latter of which a combination of ACEI and ARB might be used. It has been estimated that approximately $50-60 \%$ of those prescribed loop diuretics have heart failure as a diagnosis $[39,40]$. Although patients with heart failure usually benefit from the use of $\beta$-adrenoceptor blockers and ACEls, we did not include 
these medications as surrogates for heart failure. We did not include ACEls as this would have interfered with the population under study who were prescribed combination therapy of ACEls and ARBs. $\beta$-adrenoceptor blockers were not included as a surrogate because this would have markedly underestimated the true percentage of the population with heart failure. In a retrospective cohort study involving 9311 patients with confirmed heart failure in the United Kingdom, $79.6 \%$ were prescribed loop diuretics, $71.1 \%$ were prescribed ACEls while only $36.5 \%$ were prescribed $\beta$-adrenoceptor blockers [41]. In the cohort of hypertensive patients, the use of major classes of antihypertensives besides ACEls and ARBs excluded those prescribed monotherapy with an ACEI or ARB. However, we found no differences in gender and age profiles of patients receiving each major class of antihypertensive agent compared with those prescribed monotherapy with an ACEI or ARB.

The database used only covers one third of the Irish population with an over-representation of females, the elderly and those who are economically deprived. Previous studies have shown inequalities in prescribing across gender, age and socioeconomic groups in the Irish population $[42,43]$. This study may underestimate the true prescribing trends in Ireland especially in young males and those from higher socioeconomic groups.

\section{Implications}

In view of the conflicting results from major trials on co-prescribing of ACEls and ARBs and the increasing trends of co-prescribing in the Irish population, a local guideline on the use of these agents in specific patient populations may be needed to address the issue. Population based studies on the clinical outcomes of patients co-prescribed ACEls and ARBs can complement the results of clinical trials in the general public population.

In conclusion, increased in co-prescribing of ACEls and ARBs was observed in Ireland. Co-prescribing patterns do not appear to be affected by results from major trials. A local guideline on the use of dual therapy in specific patient population may be needed to address the issue.

\section{Competing interests}

There are no competing interests to declare.

We would like to thank the HSE-PCRS for providing the database on which this study is based.

\section{REFERENCES}

1 Weir M. Effects of renin-angiotensin system inhibition end-organ protection: can we do better? Clin Ther 2007; 29 : 1803-24.
2 Heerspink H, Perkovik V, de Zeeuw D. Renal and cardio-protective effects of direct renin inhibition: a systematic literature review. J Hypertens 2009.

3 Cohn JN, Tognoni G, the Valsartan Heart Failure Trial Investigators. A randomized trial of the angiotensin-receptor blocker valsartan in chronic heart failure. N Engl J Med 2001; 345: 1667-75.

4 McMurray JJ, Ostegren J, Swedberg K, Granger CB, Held P, Michelson EL, Olofsson B, Yusuf S, Pfeffer MA, CHARM Investigators and Committees. Effects of candesartan in patients with chronic heart failure and reduced left-ventricular systolic function taking angiotensin-converting-enzyme inhibitors: the CHARM-Added trial. Lancet 2003; 362: 767-71.

5 Mogensen CE, Neldam S, Tikkanen I, Oren S, Viskoper R, Watts RW, Cooper ME. Randomised controlled trial of dual blockade of renin-angiotensin system in patients with hypertension, microalbuminuria, and non-insulin dependent diabetes: the candesartan and lisinopril microalbuminuria (CALM) study. BMJ 2000; 321: 1440-44.

6 The Ontarget Investigators. Telmisartan, ramipril, or both in patients at high risk for vascular events. N Engl J Med 2008; 358: 1547-59.

7 Nakao NYA, Morita H, Takada M, Kayano T, Ideura T. Combination treatment of angiotensin-II receptor blocker and angiotensin-converting-enzyme inhibitor in non-diabetic renal disease (COOPERATE): a randomised controlled trial. Lancet 2003; 361: 117-24.

Retracted: Lancet 2009; 374:1126

8 MacKinnon MSS, Akbari A, Knoll GA, Jaffey J, Clark HD. Combination therapy with an angiotensin receptor blocker and an ACE inhibitor in proteinuric renal disease: a systematic review of the efficacy and safety data. Am J Kidney Dis 2006; 48: 8-20.

9 Pfeffer MA, McMurray JJV, Velazquez EJ, Rouleau J-L, Kober L, Maggioni AP, Solomon SD, Swedberg K, Van de Werf F, White $H$, Leimberger JD, Henis M, Edwards S, Zelenkofske S, Sellers MA, Califf RM, the Valsartan in Acute Myocardial Infarction Trial I. Valsartan, captopril, or both in myocardial infarction complicated by heart failure, left ventricular dysfunction, or both. N Engl J Med 2003; 349: 1893-906.

10 Khan NA, Hemmelgarn B, Herman RJ, Bell CM, Mahon JL, Leiter LA, Rabkin SW, Hill MD, Padwal R, Touyz RM, Larochelle P, Feldman RD, Schiffrin EL, Campbell NR, Moe G, Prasad R, Arnold MO, Campbell TS, Milot A, Stone JA, Jones C, Ogilvie RI, Hamet P, Fodor G, Carruthers G, Burns KD, Ruzicka M, DeChamplain J, Pylypchuk G, Petrella R, Boulanger JM, Trudeau L, Hegele RA, Woo V, McFarlane P, Vallée M, Howlett J, Bacon SL, Lindsay P, Gilbert RE, Lewanczuk RZ, Tobe S. Canadian Hypertension Education Program. The 2009 Canadian Hypertension Education Program recommendations for the management of hypertension: part 2 - therapy. Can J Cardiol 2009; 25: 287-98.

11 Messerli $\mathrm{FH}$. The sudden demise of dual renin-angiotensin system blockade or the soft science of the surrogate end point. J Am Coll Cardiol 2009; 53: 468-70. 
12 Ravandi A, Teo KK. Blocking the renin-angiotensin system: dual- versus mono-therapy. Expert Rev Cardiovasc Ther 2009; 7: 667-74.

13 Health Service Executive. Finance Shared Services Primary Care Reimbursement Services Statistical Analysis of Claims and Payments 2007. Dublin: Health Service Executive, 2007.

14 Wagner A, Soumerai S, Zhang F, Ross-Degnan D. Segmented regression analysis of interrupted time series studies in medication use research. J Clin Pharm Ther 2002; 27: 299-309.

15 Kabir Z, Feely J, Bennett K. Primary care prescribing patterns in Ireland after the publication of large hypertension trials. Br J Clin Pharmacol 2007; 64: 381-5.

16 Bennett K, Johnson H, Dack P, Shelley E, Feely J. Changes in prevalence of and prescribing for ischaemic heart disease in Ireland 1990-2002. Ir J Med Sci 2005; 174:4-8.

17 Bennett K, Williams D, Feely J. Under-prescribing of cardiovascular therapies for diabetes in primary care. Eur J Clin Pharmacol 2003; 58: 835-41.

18 Wolf-Maier K, Cooper RS, Banegas JR, Giampaoli S, Hense H-W, Joffres M, Kastarinen M, Poulter N, Primatesta $P$, Rodriguez-Artalejo F, Stegmayr B, Thamm M, Tuomilehto J, Vanuzzo D, Vescio F. Hypertension prevalence and blood pressure levels in 6 European countries, Canada, and the United States. JAMA 2003; 289: 2363-69.

19 International Diabetes Federation. Diabetes Atlas, 4th edn. Brussels: International Diabetes Federation, 2008.

20 Balanda KP, Barron S, Fahy L. Making Chronic Conditions Count: Hypertension, Coronary Heart Disease, Stroke, Diabetes. A systematic approach to estimating and forecasting population prevalence on the island of Ireland. Executive Summary. Dublin: Institute of Public Health in Ireland, 2010. pp. 7-8.

21 Cooper WO, Hernandez-Diaz S, Arbogast PG, Dudley JA, Dyer S, Gideon PS, Hall K, Ray WA. Major congenital malformations after first-trimester exposure to ACE inhibitors. N Engl J Med 2006; 354: 2443-51.

22 Quan A. Fetopathy associated with exposure to angiotensin converting enzyme inhibitors and angiotensin receptor antagonists. Early Hum Dev 2006; 82: 23-8.

23 Sever P. New hypertension guidelines from the National Institute for Health and Clinical Excellence and the British Hypertension Society. J Renin Angiotensin Aldosterone Syst 2006; 7:61-3.

24 Mancia G, De Backer G, Dominiczak A, Cifkova R, Fagard R, Germano G, Grassi G, Heagerty AM, Kjeldsen SE, Laurent S, Narkiewicz K, Ruilope L, Rynkiewicz A, Schmieder RE, Struijker Boudier HAJ, Zanchetti A, Guidelines ESCCFP, Vahanian A, Camm J, De Caterina R, Dean V, Dickstein K, Filippatos G, Funck-Brentano C, Hellemans I, Kristensen SD, McGregor K, Sechtem U, Silber S, Tendera M, Widimsky P, Zamorano JL, Council ESHS, Kjeldsen SE, Erdine S, Narkiewicz K, Kiowski W, Agabiti-Rosei E, Ambrosioni E, Cifkova R, Dominiczak A, Fagard R, Heagerty AM, Laurent S, Lindholm LH, Mancia G, Manolis A, Nilsson PM, Redon J, Schmieder RE, Struijker-Boudier HAJ, Viigimaa M,
Document R, Filippatos G, Adamopoulos S, Agabiti-Rosei E, Ambrosioni E, Bertomeu V, Clement D, Erdine S, Farsang C, Gaita D, Kiowski W, Lip G, Mallion J-M, Manolis AJ, Nilsson PM, O'Brien E, Ponikowski P, Redon J, Ruschitzka F, Tamargo J, van Zwieten P, Viigimaa M, Waeber B, Williams B, Zamorano JL. 2007 Guidelines for the management of arterial hypertension: the task force for the management of arterial hypertension of the European Society of Hypertension (ESH) and of the European Society of Cardiology (ESC). Eur Heart J 2007; 28: 1462-536.

25 Graham I, Atar D, Borch-Johnsen K, Boysen G, Burrel G, Cifkova R, Dallongeville J, De Backer G, Ebrahim S, Gjelsvik B, Hermann-Lingen C, Hoes AW, Humphries S, Knapton M, Perk J, Priori SG, Pyorala K, Reiner Z, Ruilope L, Sans-Menendex S. European guidelines on cardiovascular disease prevention in clinical practice: full text. Fourth joint task force of the European Society of Cardiology and other societies on cardiovascular disease prevention in clinical practice (constituted by representatives of nine societies and by invited experts). Eur J Cardiovasc Prev Rehabil 2007; 14: S1-113.

26 European Society of Cardiology, Heart Failure Association of the ESC (HFA), European Society of Intensive Care Medicine (ESICM), Dickstein K, Cohen-Solal A, Filippatos G, McMurray JJV, Ponikowski P, Poole-Wilson PA, Stromberg A, van Veldhuisen DJ, Atar D, Hoes AW, Keren A, Mebazaa A, Nieminen M, Priori SG, Swedberg K. ESC Guidelines for the diagnosis and treatment of acute and chronic heart failure 2008: the task force for the diagnosis and treatment of acute and chronic heart failure 2008 of the European Society of Cardiology. Developed in collaboration with the Heart Failure Association of the ESC (HFA) and endorsed by the European Society of Intensive Care Medicine (ESICM). Eur J Heart Fail 2008; 10: 933-89.

27 Van de Werf F, Bax J, Betriu A, Blomstrom-Lundqvist C, Crea F, Falk V, Filippatos G, Fox K, Huber K, Kastrati A, Rosengren A, Steg PG, Tubaro M, Verheugt F, Weidinger F, Weis M, Guidelines ESCCFP, Vahanian A, Camm J, De Caterina R, Dean V, Dickstein K, Filippatos G, Funck-Brentano C, Hellemans I, Kristensen SD, McGregor K, Sechtem U, Silber S, Tendera M, Widimsky P, Zamorano JL, Document R, Silber S, Aguirre FV, Al-Attar N, Alegria E, Andreotti F, Benzer W, Breithardt O, Danchin N, Mario CD, Dudek D, Gulba D, Halvorsen S, Kaufmann P, Kornowski R, Lip GYH, Rutten F. Management of acute myocardial infarction in patients presenting with persistent ST-segment elevation: the Task Force on the management of ST-segment elevation acute myocardial infarction of the European Society of Cardiology. Eur Heart J 2008; 29: 2909-45.

28 Vikman S, Airaksinen K, Peuhkurinen K, Tierala I, Majamaa-Voltti K, Niemela M, Niemela K. Gap between guidelines and management of patients with acute coronary syndrome without persistent ST elevation. Finnish prospective follow-up survey. Scand Cardiovasc J 2003; 37: 187-92.

29 McKee S, Leslie S, LeMaitre J, Webb D, Denvir M. Management of chronic heart failure due to systolic left ventricular dysfunction by cardiologist and non-cardiologist physicians. Eur J Heart Fail 2003; 5: 549-55. 
30 William D, Kelly A, Feely J. Influence of media and regulatory changes on prescribing of cotrimoxazole and trimethoprim in Ireland. Pharmacoepidemiol Drug Saf 2000; 9: 313-7.

31 Mason A. New medicines in primary care: a review of influences on general practitioner prescribing. J Clin Pharm Ther 2008; 33: 1-10.

32 Walley T, Follino-Gallo P, Stephens P, Van Ganse E. Trends in prescribing and utilization of statins and other lipid lowering drugs across Europe 1997-2003. Br J Clin Pharmacol 2005; 60: 543-51.

33 Feely J, Bennett K. Epidemiology and economics of statin use. Ir Med J 2008; 101: 188-91.

34 Mann JF, Schmieder RE, McQueen M, Dyal L, Schumacher H, Pogue J, Wang X, Maggioni A, Budaj A, Chaithiraphan S, Dickstein K, Keltai M, Metsärinne K, Oto A, Parkhomenko A, Piegas LS, Svendsen TL, Teo KK, Yusuf S, ONTARGET investigators. Renal outcomes with telmisartan, ramipril, or both, in people at high vascular risk (the ONTARGET study): a multicentre, randomised, double-blind, controlled trial. Lancet 2008; 372: 547-53.

35 Fried LF, Duckworth W, Zhang JH, O'Connor T, Brophy M, Emanuele N, Huang GD, McCullough PA, Palevsky PM, Seliger S, Warren SR, Peduzzi P, for VAN-DI. Design of combination angiotensin receptor blocker and angiotensin-converting enzyme inhibitor for treatment of diabetic nephropathy (VA NEPHRON-D). Clin J Am Soc Nephrol 2009; 4: 361-68.
36 Von Korff M, Wagner EH, Saunders K. A chronic disease score from automated pharmacy data. J Clin Epidemiol 1992; 45 : 197-203.

37 Maio V, Yuen E, Rabinowitz C, Louis D, Jimbo M, Donatini A, Mall S, Taroni F. Using pharmacy data to identify those with chronic conditions in Emilia Romagna, Italy. J Health Serv Res Policy 2005; 10: 232-38.

38 Naughton C, Bennett K, Feely J. Prevalence of chronic disease in the elderly based on a national pharmacy claims database. Age Ageing 2006; 35: 633-36.

39 Clarke K, Gray D, Hampton J. How common is heart failure? Evidence from PACT (prescribing analysis and cost) data in Nottingham. J Public Health Med 1995; 17: 459-64.

40 Sparrow N, Adlam D, Cowley A, Hampton J. The diagnosis of heart failure in general practice: implications for the UK National Service Framework. Eur J Heart Fail 2003; 5: 349-54.

41 Calvert M, Shankar A, McManus R, Ryan R, Freemantle N. Evaluation of the management of heart failure in primary care. Fam Pract 2009; 26: 145-53.

42 Odubanjo E, Bennett K, Feely J. Influence of socioeconomic status on the quality of prescribing in the elderly- $\mathrm{a}$ population based study. Br J Clin Pharmacol 2004; 58: 496-502.

43 Bennett K, Williams D, Feely J. Inequalities in prescribing of secondary preventative therapies for ischaemic heart disease in Ireland. Ir Med J 2002; 95: 169-72. 